\title{
Education as a fundamental right and human rights acquired through education
}

\author{
Blendi Dibra \\ Name of Institution North University Argenty \\ Albania \\ bdibra@gmail.com
}

DOI:10.5901/mjss.2014.v5n19p155

\begin{abstract}
The right to education is an essential tool conditions for the development of an emancipated societies, to maintain and strengthen their cultural identities, ethnic and linguistic minorities. Education can promote (though not guarantee) understanding, tolerance, respect and friendship between peoples, ethnic or religious groups and can help create a universal culture of human rights. So education is an individual expression of freedom that it is an economic necessity from which depends the development of the country. Provision of education should be considered as a long term investment with high priority, because it develops human resources as an asset in the process of national development. So full realization of the right to education can be achieved by improving the economic, social and cultural rights through a political commitment and cooperation of the all. From historical point of view, the education in Europe, before the age of enlightenment, was primarily the responsibility of parents and the church. Education began to become public affair and state responsibility only with the constitution of the modern secular state. In the century XIX, the emergence of socialism and liberalism placed education, more strongly, in the field of human rights. Liberal and anti-clerical ideas of the XIX century influenced to the definition of the right to education which aimed to protect and advance the ideas of freedom, of science, of research and teaching against the every influencing forms from the church and the state. Principles of the right to education was included in the Universal Declaration of Human Rights and national constitutions and various international and national instruments charge states with the obligation to respect, protect and fulfill all the rights to education because the fundamental right to education entitles all individuals to provide appropriate forms of behavior from their respective governments. Ensuring citizens with many civil and political rights, such as the right to information, freedom of expression, the right to vote and to be elected, and many others, depend on at least a minimum level of education. So thats why its so important the right to education as far as it provides to the citizens more control over the course of their life, in particular, control over the actions of the state against the citizens in general.
\end{abstract}

Keywords: Education, fundamental right ,human rights

\section{A brief historical overview}

In Europe before the age of enlightenment, education was primarily the responsibility of parents and the church. Education began to become public affairs and state responsibility only with the emergence of the modern secular state.

In the XIX-th century, the emergence of socialism and liberalism placed, more strongly, education in the field of human rights. Liberal and anti-clerical thoughts of the XIX century influenced to the definition of the right for education which was formulated to protect and advance the ideas of freedom of science, research and teaching against the intervention of church and state.

Aspects of the right for education was included in the Universal Declaration of Human Rights and national constitutions.

The right for education has been explicitly mentioned in the constitutions of the fifty-two countries, such as Nicaragua, Cyprus, Spain, Vietnam, Ireland, Egypt, Japan, Paraguay and Poland.

The Constitution of the United States does not mention any right to education but courts in U.S, at both levels, have developed certain chapters to education, particularly with regard to equality of opportunities for education.

\section{Human rights acquired through Education}

The fundamental right to education entitles all individuals to provide appropriate forms of behavior to their respective governments. So as mentioned above, various international and national instruments charges states with the obligation to 
respect, protect and fulfill the rights of everyone for education. States should, beside other rights, respect the freedom of parents to choose public or private schools for the education of their children's and ensure to them moral and religious education according to their own convictions.

The need for the equally education of the boys and girls shall be respected, same as for all religious, ethnic and linguistic groups. States should ensure that private schools do not apply discriminatory practices or do not violate human rights1. This obligation requires from states to take steps through legislation or other mechanisms to protect and prevent violations of individual freedoms and rights from third parties.

\section{The role of education in strengthening human security}

Education is more than learning how to read, write or calculate. The right of individuals for education includes the possibility of their involvement in primary, secondary and higher education.

Since the concept of the right to education is quite broad, the term primarily focus on elementary or primary education, because most people are deprived of even of the foundations of learning which last for the whole life. It's very shocking the fact that around 1 billion people entered the XXI century unable to read a book or to sign their name2.

Denial and violation of the right for education undermines people's capacities to develop their personalities, to support and protect themselves and their families, as well as to participate actively in the social, political and economic life. In a society, the denial of education, harms the cause of democracy and social progress and therefore human security. Through education and learning process about human rights may be prohibited or regulated violations of human rights and armed conflicts, and can be facilitated social reconstruction after the end of conflicts.

\section{Sanctioning of the right to education}

The human right for education, as one of the basic human rights, It's written in several regional and papers for human rights which have been ratified by many countries of the world by finding the right support and expression in the Constitutions and legislations of these countries.

Therefore, the right to education has a consolidated basis in the international law for human rights. Some of the universal documents are:

Universal Declaration of Human Rights (Article 26),

International Pact for Economic, Social and Cultural rights (Article 13 and 14)

Convention for elimination of all forms of discrimination against womens. (Article 10)

Convention about Children Rights (Article 28 and 29).

Some of the regional documents are:

- European Convention for Fundamental Protection of the Human Rights and Freedoms (Article 2, first Protocol),

- American Convention on Human Rights (Article 13 of the Additional Protocol of the American Convention on Human Rights in the area of economic, social and cultural rights)

- African card for Human and peoples Rights (Article 17).

As one of the most important documents of the Universal Declaration of Human Rights in its Article 26, expresses quite clear that:

\footnotetext{
${ }^{1}$ Article 13, paragraph 1, of the International Covenant on Civil and Political Rights, says:

"...education should be directed toward the development of human personality and dignity of his feelings and strengthening respect for human rights and fundamental freedoms. Education shall enable all persons to participate effectively in a free society, to support understanding, tolerance and friendship of all nations and all racial, ethnic or religious; advancing the activities of the United Nations in peacekeeping"

${ }^{2} \mathrm{~A}$ wise expression says: "Education is the best defender of freedom, than a whole army"
} 
- Everyone has the right for education. Education shall be free, at least in the elementary and fundamental stages. Primary education is compulsory. Technical and vocational education should be expanded and higher education should be made available to everyone on the basis of merits.

- Education shall be directed to the full development of the human personality and to the strengthening of respect for human rights and fundamental freedoms. It shall promote understanding, tolerance and friendship among all nations, racial or religious groups, and the United Nations for the maintenance of peace.

- The right to choose the kind of education for their children's firstly belong to their parents.

Also Protocol no.1 of the European Convention for the Protection of Human Rights and Fundamental Freedoms, the right to education defines in the article 2 of its 1 as following:

"None shall be denied to the right to education. State, in the exercise of the functions which it assumes in relation to education and to teaching, respects the right of parents to ensure such education and teaching in conformity with their religious and philosophical beliefs."

In Albania the right to education is forced, first of all, in the main document in Constitution precisely in Chapter IV on "freedoms and economic, social and cultural rights" in the article 57, where the given definition is consistent with the fundamental principles of international instruments of human rights cited above.

The main elements of state obligations arising from universal, regional and national documents the possibility of establishing the right to education are:

Disponibility,

possibility of access,

acceptance

adaptation

\section{a.Disponibility}

In this element as essential condition for the realization of the right to education its introduced the obligation to provide compulsory and free primary education. These include financial and political commitment to ensure primary schools for all children.

\section{b.Possibility of access}

Minimum obligation of governments is to ensure the realization of the right to education through guaranteeing participation in existing institutions of all, girls and boys, women's and men's, on the basis of equality and without discrimination.

\section{c.Acceptance}

This element includes the right to choose the accepted education and the right to establish, maintain, manage and control private educational institutions. Students and parents have the right to be free from indoctrination as such, mandatory study of materials that are incompatible with religious or other beliefs, the student may violate the right to education.

In the Framework Convention for the Protection of National Minorities, the European Council has recognized the right to learn the mother tongue, but did not recognize at the same time the right to receive instruction in their native language.

European Charter for Regional or Minority Languages has gone a step further in promoting the right to education in the mother tongue as an option for those states that have signed the Charter. The goal of bilingualism, of minorities in those

\footnotetext{
1 Protocol Nr. 1 of European Convention for Protection of the Human Right and Fundamental Freedoms in the article 2 says "None shall be denied the right to education. State, in the exercise of the functions which it assumes in relation to education and to teaching, respects the right of parents to ensure such education and teaching in conformity with their religious beliefs and philosophical."
} 
countries is recognized by the state. However, there are minorities who are not protected in this way and not even have the right to learn their mother tongue, such as the Roma in Europe and the Aborigines in Australia.

\section{d.Adoption}

Normally, what a child learns in school should be determined by his or her needs for the future. This means that the educational system must be adaptable, taking into account the best interests of the child, but also social development and progress in national and international scale. Governments are obliged to ensure that human rights education is respected, protected and fulfilled. It is also the duty of civil society to promote and assist the full implementation of the right to education.

\section{Conclusions:}

The right to education provides the individual more control over the course of his life, in particular, control over the actions of the state against the individual. Enjoyment of many civil and political rights, such as the right to information, freedom of expression, the right to vote and to be elected, and many others, depend on at least a minimum level of education.

Also, a number of economic, social and cultural rights such as the right to choose job, to receive equal pay for equal work, to enjoy the benefits of scientific and technological progress and get higher education based on skills, can be exercised in a meaningful way if it's achieved at least a minimum level of education.

Literacy levels simultaneously expands the right to participate in cultural life. As one of the main conditions for the development of an emancipated society, ethnic and linguistic minorities, the right to education is an essential tool to maintain and strengthen their cultural identity. Education can promote (though not guarantee) understanding, tolerance, respect and friendship between peoples, ethnic or religious groups and can help create a universal culture of human rights.

So education is an individual expression of freedom that it is an economic necessity from which depends the development of the country. Provision of education should be considered as a long term investment with high priority, because it develops human resources as an asset in the process of national development.

So full realization of the right to education can be achieved by improving the economic, social and cultural rights through a political commitment and cooperation of the all.

Therefore the development of education as one of the key elements for the realization of social change in each country in direct and indirect way imposes political emancipation and rightly Brougham Lord says: "Education makes people easy to lead, but difficult to enforce, manageable to govern, but impossible to enslave"

\section{REFERENCES}

David Betham, 1998. Human rights: New dimensions and challenges. Edited by Janusz Simonides. Democracy and human rights: civil, Political Economic, social and cultural. Handbook on Human Rights. Published by UNESCO.

Ivet Daoudes and Kishor Sinh. 2001. Right to education: an analysis of instruments for the regulation of UNESCO's standards. Paris. Published by UNESCO.

Janus Simonides. 2000. Human Rights: Concepts and Standards. Aldershot: Ashgate Publishing.

Katarina Tomasevsky. 1999. Preliminary Report of the Special Reporter on the Right to Education,UN, doc, E/CN.4/1999/49.

United Nations. 2001. We the People: The Role of United Nations in the 21st century, Briefing Papers for Students. New York. UN publications.

Council of Europe. 2002. COMPASS - Manual on Human Rights Education with Young People. Year 2002. Strasbourg: Council of Europe.

Fons Komans, 1998. Identifying Violations of the right to education. Edited by Van Boven, Theo, Flinterman and Ingrid Westendorp. Maastricht Guidelines on Violations of Economic, Social and Cultural Rights, SIM Special no.20. Utrecht: Netherlands Institute for Human Rights. 
Fons Komans, 1995. Clarifying the key elements of the right to education. Edited by Komans, Fons and Van Hof. The right to complain about the right economic, social and cultural. SIM Special no. 18. Utrecht: Netherlands Institute for Human Rights .

Resource Center of Human Rights. Circle of Rights. Activities on Economic, Social and Cultural Rights: A Training Resource. Available at the web address: http://hrusa.org/hrmaterials/IHRIP/circle/toc.htm

Office of the High Commissioner of the United Nations on Human Rights. 1999. UN Decade on Education for Human Rights (1995-2004) no.3. Compilation of provisions of international and regional instruments dealing with human right to education. Geneva, United Nations. 